\title{
FEATURES OF ASSESSMENT AND FORECASTING OF SOCIO-ECONOMIC DEVELOPMENT OF REGIONS IN UKRAINE
}

\author{
Serhii Makarenko' ${ }^{1}$ Nataliia Oliinyk², Tetiana Kazakova ${ }^{3}$
}

\begin{abstract}
The purpose of the article is to carry out an analysis and improvement of the methodological approach for estimating and forecasting socio-economic devel-opment of regions. The methodological basis of the study consisted of scientific works of domestic and foreign scientists and leading specialists, statistical and analytical materials of state authorities. The results are obtained through the use of such methods as: expert - to identify the impact of qualitative and quantitative indicators on the socio-economic development of the region; economicmathematical analysis - to study the influence of a defined group of indicators on the level of development of the region; abstract-logical - for a theoretical synthesis and formulation of conclusions. The results of the study suggest that the introduction of a sound scientific and methodological approach to assessing and forecasting the level of development of the country and regions in particular will allow not only to identify problem areas in the development of the respective territories, but also to get the potential investor reliable information about the real state of affairs and to determine the justification of further investment in the activity of the research object. Using an unjustified scientific and methodological approach not only can distort the real state of affairs in the regions and the country in general, but also send limited financial resources of the State and local budgets in the conditions of the crisis to improve the indicators that have a minor impact on the development of the economy. It is proved that in current crisis conditions, the functioning of the national economy, state authorities should implement a more effective discretionary fiscal policy aimed at reducing the tax burden in the formation of the wage fund of the socially vulnerable population. The errors, ob-tained during misuse of information technologies in the assessment of socio-economic development of regions are revealed. The scientific and methodological approach to determining the coefficient of competence of experts and the value of 1 point of qualification competences during the construction of forecast scenarios and the development of regional economic development programs using intuitive fore-casting methods has been improved. Proposals for improving the system of taxation of the socially vulnerable population are developed.
\end{abstract}

Key words: assessment, forecasting, socio-economic development, coefficient of competence, taxation of the socially vulnerable population.

JEL Classification: $\mathrm{H} 21, \mathrm{H} 70, \mathrm{O} 11$

\section{Introduction}

The development of market transformations in the country and its regions is impossible without reforming of the fiscal system based on a fundamentally new model of its organization - fiscal decentralization, which provides for the extension of powers of local selfgovernment bodies in the tax area in order to obtain financial leverage for the socio-economic development of their territories, expansion of the local tax base. This is precisely what the introduction of a regional

\footnotetext{
Corresponding author:

${ }^{1}$ Kherson State University, Ukraine.

E-mail: makar0684@gmail.com

ORCID: https://orcid.org/0000-0001-9929-8967

ResearcherID: https://publons.com/researcher/1878529/serhii-makarenko/

${ }^{2}$ Kherson National Technical University, Ukraine.

E-mail: nat-o@ukr.net

ORCID: https://orcid.org/0000-0002-1019-5708

${ }^{3}$ Kherson State University, Ukraine.

E-mail: Kazakova@ksu.ks.ua

ORCID: https://orcid.org/0000-0003-1680-7653

ResearcherID: https://publons.com/researcher/3591913/tetiana-kazakova/
} 
tax policy requires, the formation and implementation of which should be undertaken both by the state and local authorities. The new administrative and territorial unit should become the basis for constructing a new territorial management model based on the principles of decentralization, subsidiarity, balance of national interests with the interests of the population of regions and territorial communities, the widespread local self-government, the capacity and independence of territorial communities to address local issues. In the current unstable business environment, the main task for local governments is to learn how to plan their development and use resources of updated budgets efficiently; for state bodies - to substantiate and transparently assess the state of socio-economic development of administrative and territorial units of all levels and ensure implementation of the general forecast of the country development and individual regions in particular.

In current conditions of unstable business environment, state authorities and local self-government bodies, together with representatives of the economic entities, are interested in developing a coherent mechanism for reliable assessment of the level of socioeconomic development and the construction of an effective forecast model that will determine the impact of the most important factors on the productive indicator and outline the plan for further measures regarding the development of administrative and territorial units.

The purpose of the article is to carry out an analysis and improvement of the methodological approach for estimating and forecasting socio-economic development of regions.

\section{Features of definition of forecast scenarios of socio-economic development of regions}

The research of the modern specifics and methodological approaches to the evaluation and forecasting of socio-economic development of administrative and territorial units in the short and medium term in their analytical works was carried out by specialists of state authorities - Cabinet of Ministers of Ukraine (2011; 2012), State Statistics Service of Ukraine (2018), scientific institutions Scientific Research Center for Industrial Problems of Development of the National Academy of Sciences of Ukraine (2018), as well as representatives of scientific community - I. Bohdaniuk, V. Kolisnichenko, \& O. Ustymenko (2018), B. Guziejewska (2015), M. V. Kichurchak (2016), O. V. Lozova (2012), N. I. Soloviova, S. M. Makarenko, \& N. M. Oliinik (2016), N. A. Tyukhtenko, S. M. Makarenko (2019), I. V. Yaroshenko, \& I. B. Semyhulina, N. Zachosova (2019). Despite significant work, there remain problems requiring additional scientific analysis, especially as regards the justification for using the proposed group of indicators and the methodology for assessing and forecasting socio-economic development of the regions.

In Ukraine, the bulk of the national product is created in certain sectors and regions, and the current situation is urgent in reducing territorial disproportions, expanding interregional cooperation in the markets of goods, services, capital and labor. Effective regulation of regional development ensures the functioning of the national economy as an integral system based on the optimal allocation of productive forces, taking into account local resources, existing settlement systems, and the peculiarities of historical development. The basis for such regulation should be the real assessment and construction of a sound forecast of socio-economic development of the country and regions in particular.

Without qualitative information it is impossible to make the right decision, but it is much more difficult to use this information in practice. In determining the optimal development strategy, the necessary condition is the development of appropriate effective methods and tools for managing entities of all forms of ownership and the region in general. One of the most important tools is modeling and forecasting socio-economic processes. The forecasting scheme should take into account not only stable tendencies of the basic parameters functioning of the regional economic complex or its environment, but also circumstances that cannot be reflected in formal mathematical models.

Typically, in constructing forecast of socio-economic development scenarios of the region, the following sequence of actions is carried out (Figure 1).

As we see from the given chain of actions, during the forecast development of the region, work begins with the definition of the bases observation and the search for information sources, which greatly complicates the modeling of socio-economic processes of the region: the basis of the indicators of economic and social develop-ment, which do not have significant impact on the overall indicator of the region's development.

The results of previous surveys (Soloviova, Makarenko, Oliinyk, 2016) suggest that the lack of a well-founded and correct model of assessment and forecasting of socio-economic development of regions does not allow public authorities and local government to determine an effective set of measures aimed at development of territories, which, as a result, leads to inefficient and ineffective use of funding sources for the implementation and improving of measures that have little impact on the region's economy. Also, the lack of a reliable assessment of socio-economic development level undermines the trust of foreign investors in domestic sources of information, which is reflected on official websites of central authorities (Ministry of Economic Development and Trade of Ukraine, State Statistics Service of Ukraine, etc.), which leads to deterioration of investment the attractiveness of the domestic economy and the reduction of the foreign direct investment attraction. 


\begin{tabular}{|c|}
\hline Construction of forecast scenarios of socio-economic development of the region \\
\hline 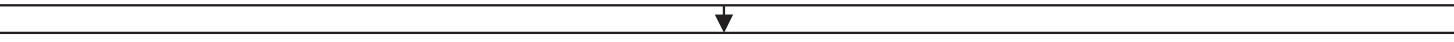 \\
\hline $\begin{array}{l}\text { Collection of specialized structural subdivisions of district state administrations, city executive committees } \\
\text { of cities of regional importance of information from business entities of the region regarding their forecast } \\
\text { performance and development indicators }\end{array}$ \\
\hline 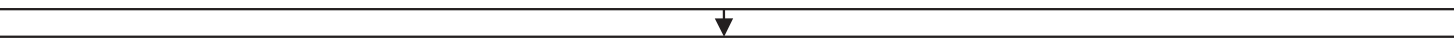 \\
\hline $\begin{array}{l}\text { Generalization of district state administrations, city executive committees of cities of regional significance } \\
\text { of given information, and based on it, taking into account the tendencies of recent years, providing } \\
\text { proposals on quantitative and qualitative changes in indicators of the region's development for the next } \\
\text { years and the necessary set of measures for the accomplishment of the tasks set to the specialized } \\
\text { structural subdivision of the regional state administration }\end{array}$ \\
\hline$\downarrow$ \\
\hline $\begin{array}{l}\text { Analysis and generalization of the submitted subdivisions of the regional state administration, formation } \\
\text { of the project of the forecast (program) of the region development }\end{array}$ \\
\hline$\gamma / \frac{1}{2}$ \\
\hline $\begin{array}{l}\text { Approval of the draft forecast (program) of the development of the region in accordance with the } \\
\text { established procedure with the head of the regional state administration and deputies (approval } \\
\text { by the chairman of the regional state administration), officials and deputies of the regional council, } \\
\text { making, if necessary, comments and proposals; approval at the session of the regional council of the } \\
\text { forecast (program) of the region's development }\end{array}$ \\
\hline
\end{tabular}

Figure 1. The sequence of actions in constructing forecast scenarios of socio-economic development of the region

Source: own elaboration based on information of the regional state administration

\section{Modern models assessment of social and economic development of the country and regions}

In order to assess and forecast the socio-economic development of the country and regions, various methodological approaches developed by both public authorities and local self-government, as well as the scientific community and public organizations, are used in particular. It deserves attention to the methodological approach provided by the Decrees of the Cabinet of Ministers of Ukraine dated June 9, 2011 No. 650 and April 9, 2012 No. 335, according to which the evaluation was conducted using 81 indicators in 10 areas of analysis. The calculations were carried out in three stages (Figure 2).

The region was considered the best, the average arithmetic mean of the sum of rating grades has the lowest value.

However, in the proposed methodological approach, some of the proposed indicators were not used in the calculation of the rating assessment in general or in relation only to the cities of Kyiv and Sevastopol. Thus, according to the results of the year, the assessment without the cities of Kyiv and Sevastopol was conducted only in 52 indicators, among which 16 indicators reflected the growth rates (indices) growth / decrease, 9 of them reflected the share of the found indicator, 19 had natural units of measurement, 8 had other units of measurement. And the other 29 indicators were informative in nature.

The proposed method of determining the total place as the average arithmetic mean of rating assessments sum of a specific region activity in all areas, established a non-transparent and mathematically unjustified action to determine the proposed in-dicators importance. Thus, the direction where only two indicators for evaluation ("Crime rate") were used had the same share in comparison with the direction, in which fourteen indicators ("Economic development") were used, which prevented the conduct of reasoned assessment and the real situation in the regions, where a relevant study was conducted.

Also, during the introduction of this methodological approach, it was not considered that the presence of a wide range of indicators could reduce the proportion of the most influential factors, and increase the probability of error in planning and forecasting, and send the authorities to implement a set of measures to improve the values of the insignificant indicators for the economy.

The above was confirmed by the conducted economicmathematical analysis, during which the system was checked for possible multicollinearity between the indicators and found a strong connection only between the gross domestic product (effective factor) and 17 indicators (with the use of official materials for 11 reporting periods from 2010 for the first half 


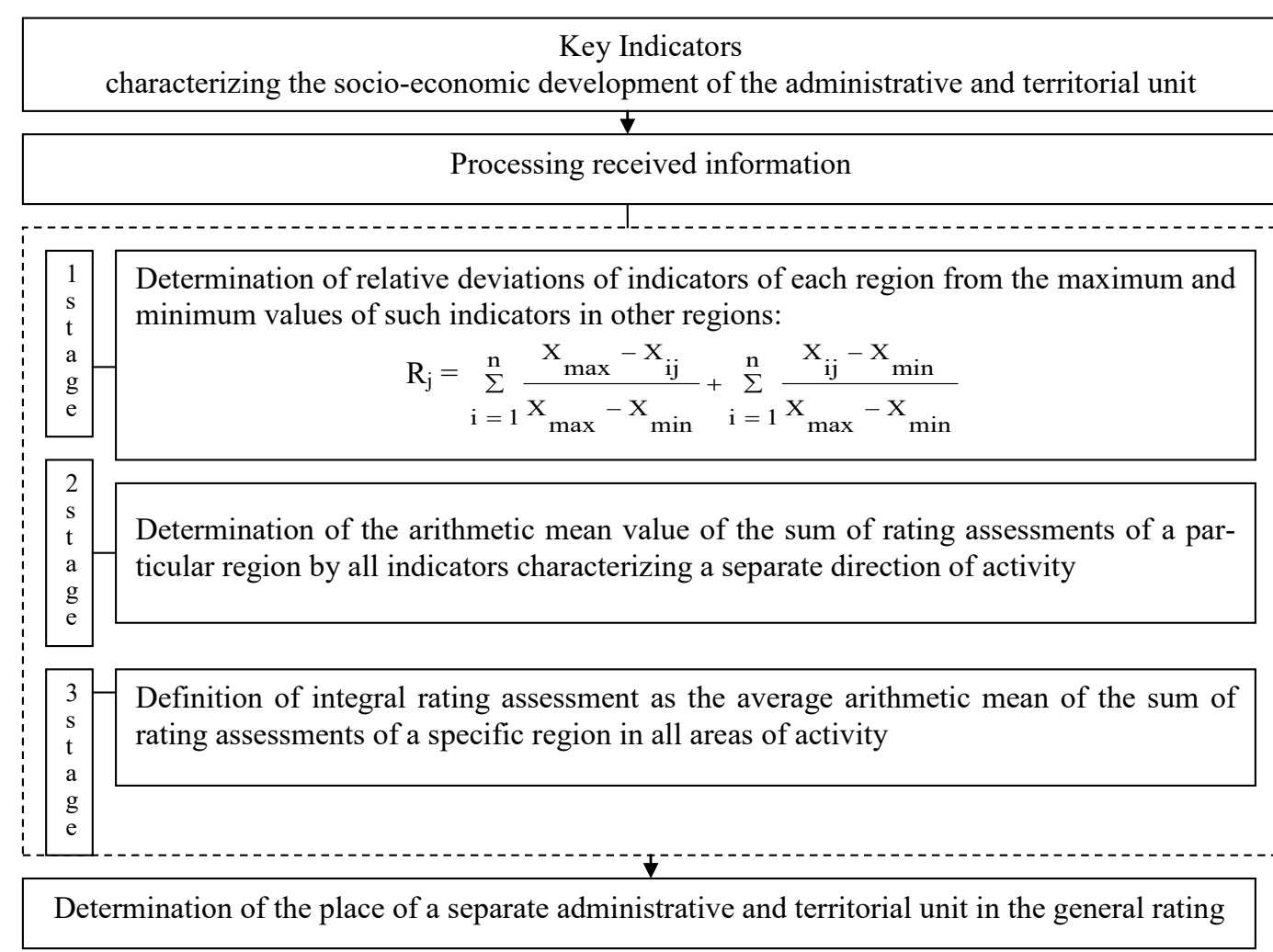

Figure 2. Methodological approach to determining the individual administrative unit location in the overall ranking

Source: own elaboration based on Resolution of the Cabinet of Ministers of Ukraine dated June 9, 2011 No. 650

of 2013). The highest correlation was observed between the gross domestic product and the volume of industrial products sold per unit of population $(\mathrm{r}=0.9963)$, the volume of agricultural production per 100 hectares of agricultural land $(r=0.9647)$, the volume of capital investments (except for investments from the state budget) per unit of population ( $\mathrm{r}=0.9891)$, volume of tax revenues to local budgets per unit of population $(r=0.9948)$, volume of commissioned housing in the calculation 10 thousand population $(\mathrm{r}=0.9639)$. These indicators actually reflected the existing system of interconnection among the population (labor resources), business entities of all forms of ownership and state institutions.

It was found that the above proposed approach included not only the disadvantages associated with the mechanism of determining the importance of indicators and the method of conducting the calculations, but also observed the reasons associated with the lack of quality training in working with specialized software from experts who conducted a quarterly assessment of the results of the regions. Thus, during the evaluation of the results of the first half of 2013 in the direction "Child Protection", there were found errors in determining the general place of each region. Despite the fact that five leaders and five outsiders did not change due to the mis-takes made in the "Child Protection" direction, there was a significant change in leaders and outsiders in accordance with the overall integrated calculations, namely: the top five leaders should have been Kyiv (1st place), Rivne (2nd against 3rd), Odesa (3rd against 4th), Crimea (4th against 2nd) and Chernivtsi (5th against 6th) region. Instead, five outsiders were supposed to make up Kherson (25th against 23rd), Sumy (24th against 25th), Lviv (23rd against 24th), Lugansk (22nd against 21st) and Zakarpattia (21st against 22nd) regions respectively.

Using various methodological approaches in Table 1, we will describe and compare the results of the conducted evaluation of the activity of the administrative and territorial units on the results of the first half-year of 2013. The conducted studies indicate that taking into account the proposals made to eliminate the mistakes made in determining the general place of each region and the weight of the proposed indicators, there would be significant changes in both the three outsiders and the three leaders.

Thus, among three regions that occupy leading positions, only Crimea would remain in the leaders, having entered the first place for each group of indicators, as well as an improved method of calculation, which determines that each indicator has the same value for the assessment of socio-economic development of regions. The results of the same indicators for the Kyiv region identify that in the case of changing the methodology 
Table 1

Assessment of the results of activity of administrative and territorial units (on the results of the first half of 2013) (using different assessment techniques)

\begin{tabular}{|c|c|c|c|c|c|c|c|c|c|}
\hline \multirow{3}{*}{ The region } & \multicolumn{5}{|c|}{$\begin{array}{l}\text { In accordance with the list of indicators provided in the resolution } \\
\text { of the Cabinet of Ministers of Ukraine No. } 650 \text { dated } 09.06 .2011\end{array}$} & \multicolumn{4}{|c|}{ According to the adjusted list of indicators } \\
\hline & \multirow[t]{2}{*}{$\begin{array}{c}\text { assessment carried } \\
\text { out by the Ministry } \\
\text { of Economic } \\
\text { Development and } \\
\text { Trade of Ukraine } \\
\text { place }\end{array}$} & \multicolumn{2}{|c|}{ adjusted score } & \multicolumn{2}{|c|}{$\begin{array}{l}\text { evaluation as a result } \\
\text { of association } \\
2 \text { and } 3 \text { stages } \\
\text { (Figure 2) }\end{array}$} & \multicolumn{2}{|c|}{$\begin{array}{l}\text { assessment that was car- } \\
\text { ried out in accordance } \\
\text { with the procedure } \\
\text { defined by the Cabinet } \\
\text { of Ministers of Ukraine } \\
\text { No. } 650 \text { dated } 09.06 .2011\end{array}$} & \multicolumn{2}{|c|}{$\begin{array}{l}\text { evaluation due } \\
\text { to the merger } \\
2 \text { and } 3 \text { stages } \\
\text { (Figure 2) }\end{array}$} \\
\hline & & coefficient & place & coefficient & place & coefficient & place & coefficient & place \\
\hline Crimea & 2 & 0.488 & 4 & 0.482 & 1 & 0.362 & 1 & 0.432 & 1 \\
\hline Vinnytsia & 14 & 0.554 & 14 & 0.555 & 13 & 0.649 & 14 & 0.64 & 20 \\
\hline Volyn & 20 & 0.573 & 18 & 0.569 & 17 & 0.591 & 8 & 0.615 & 15 \\
\hline Dnipropetrovsk & 9 & 0.527 & 8 & 0.489 & 2 & 0.649 & 15 & 0.522 & 4 \\
\hline Donetsk & 18 & 0.575 & 20 & 0.587 & 22 & 0.592 & 9 & 0.596 & 11 \\
\hline Zhytomyr & 12 & 0.549 & 12 & 0.544 & 10 & 0.699 & 20 & 0.65 & 21 \\
\hline Zakarpattia & 22 & 0.582 & 21 & 0.565 & 16 & 0.605 & 11 & 0.566 & 9 \\
\hline Zaporizhzhia & 13 & 0.552 & 13 & 0.532 & 8 & 0.553 & 5 & 0.555 & 8 \\
\hline Ivano-Frankivsk & 19 & 0.56 & 16 & 0.582 & 21 & 0.576 & 6 & 0.541 & 6 \\
\hline Kyiv & 1 & 0.473 & 1 & 0.494 & 3 & 0.458 & 3 & 0.532 & 5 \\
\hline Kirovohrad & 17 & 0.574 & 19 & 0.546 & 11 & 0.701 & 21 & 0.631 & 18 \\
\hline Luhansk & 21 & 0.602 & 22 & 0.61 & 24 & 0.585 & 7 & 0.605 & 13 \\
\hline Lviv & 24 & 0.603 & 23 & 0.609 & 23 & 0.681 & 17 & 0.622 & 17 \\
\hline Mykolaiv & 5 & 0.518 & 7 & 0.51 & 5 & 0.517 & 4 & 0.468 & 2 \\
\hline Odesa & 4 & 0.488 & 3 & 0.503 & 4 & 0.434 & 2 & 0.48 & 3 \\
\hline Poltava & 8 & 0.541 & 11 & 0.551 & 12 & 0.642 & 13 & 0.589 & 10 \\
\hline Rivne & 3 & 0.482 & 2 & 0.515 & 6 & 0.619 & 12 & 0.605 & 12 \\
\hline Sumy & 25 & 0.626 & 24 & 0.619 & 25 & 0.759 & 25 & 0.687 & 24 \\
\hline Ternopil & 7 & 0.515 & 6 & 0.573 & 18 & 0.717 & 24 & 0.696 & 25 \\
\hline Kharkiv & 16 & 0.563 & 17 & 0.556 & 14 & 0.713 & 23 & 0.667 & 22 \\
\hline Kherson & 23 & 0.626 & 25 & 0.577 & 20 & 0.658 & 16 & 0.616 & 16 \\
\hline Khmelnytskyi & 15 & 0.557 & 15 & 0.543 & 9 & 0.683 & 18 & 0.612 & 14 \\
\hline Cherkasy & 11 & 0.536 & 10 & 0.559 & 15 & 0.685 & 19 & 0.636 & 19 \\
\hline Chernivtsi & 6 & 0.513 & 5 & 0.518 & 7 & 0.597 & 10 & 0.553 & 7 \\
\hline Chernihiv & 10 & 0.535 & 9 & 0.577 & 19 & 0.704 & 22 & 0.673 & 23 \\
\hline
\end{tabular}

Source: authors' own work

of conducting the evaluation, the indicated area would not even be among the top three leaders, not to mention absolute leadership. The same goes for the Rivne region, which, in case of a change in the list of indicators and calculation methodology, could be in the second ten regions.

As for outsiders, the last and penultimate places are occupied by the Sumy region with each method of calculation and using the proposed list of indicators, confirming the crisis situation in the economy of the region. Instead, the Lviv and Kherson regions showed a significant change in positions taken for the better on 7-9 positions.

When using the official materials of the Ministry of Economic Development and Trade of Ukraine together with the State Statistics Service of Ukraine for the 14 reporting periods from 2010 to the first quarter of 2014, the authors (Soloviova, Makarenko, Oliinyk,
2016) in assessing the socio-economic development of the re-gions it is suggested to use 13 indicators. This could be related, first of all, to the possible changes in the statistical methods for the determination of individual evaluation indicators, which could lead to a distortion of the link between the effective factor and the proposed indicators.

Thus, on the example of Kherson oblast, one can state that in 2007 the results of industrial activity of one of the most powerful light industry enterprises of Ukraine and Europe in general, the budget-formative enterprise of Kherson - OJSC "Kherson Cotton Plant", were isolated from the basis of calculations, in which the number of employees in the heyday reached 23 thousand people. As a result, instead of reducing the output of industrial products of the Kherson region by more than $15 \%$ by the results of 2007 , an increase of $9.4 \%$ was received. Similar changes in the defined set of indicators could be 
observed both in different regions and in the country in general.

Today, despite the expiration of the normative legal acts, the assessment of the socio-economic development of the regions of Ukraine is carried out in the same way using the scientific and methodological approach provided by the Decrees of the Cabinet of Ministers of Ukraine No. 650 dated June 9, 2011 and No. 335 dated April 9, 2012. Minor changes only occurred in relation to the directions and number of evaluation indicators. Thus, the Department of Macroeconomic Policy and Regional Development of the Research Center for Industrial Development Problems of the National Academy of Sciences of Ukraine uses 50 key indicators in 9 areas for the monthly rating assessment of the socioeconomic development of the regions of Ukraine.

\section{The current state of functioning of state authorities and local self-government}

The development of the regional economy depends to a large extent on how reliable the experts of local government and local government itself will be able to identify the strengths and weaknesses, opportunities and threats for the regional economy; to forecast changes in the external and internal business environment and their impact on the region's economy; plan and implement a plan of measures to ensure the development of key economic activities.

At the same time, it should be kept in mind that the construction of forecast scenarios and the development of regional economic development programs are usually carried out using intuitive forecasting methods without the use of specialized software. However, even in this case, mathematical models and information technol-ogies are almost not used, which will allow to assess the level of competence of the involved experts and increase the reliability of the projected assumptions made. According to the results of the research, authors (Makarenko,
Oliinyk, Kazakova, 2018) proposed to determine the coefficient of competence of experts, depending on the experience of the position (occupied position), the existing level of education, degree, academic rank and other factors related to the object of the study. At the same time, in determining the coefficient of competence of experts, it would be advisable to also take into account the level of fluctuations of the relevant qualifications in the middle of the study group. The above will allow to transfer all qualitative and quantitative evaluation indicators into a single scale of evaluation. The proposed approach can be used not only in determining the level of competence of experts, but also in assessing the qualification level of employees (Qe) and determining the value of 1 point of qualification competencies (C) (Table 2) in the corresponding economic area. The performed calculations show that according to the proposed methodology the highest qualification level has an employee number $6(\mathrm{Qe}=17.318$ points $)$. Also, the value of 1 point of quality of the said employee is the lowest, which indicates his or her high level of competitiveness in the respective production area.

The aforementioned methodological approach in determining the level of competence of experts, based on the received calculations for three indicators of evaluation, allowed to identify their next level of competence: expert No. $1-4.14 \%$, expert No. 2 - 6.62\%, expert No. 3 - 3.89\%, expert No. 4 $3.81 \%$, expert No. 5 - 8.01\%, expert No. 6 - 53.83\%, expert No. 7 - 16.25\%, expert No. $8-3.45 \%$.

Leading experts from the educational sector, local authorities, budget-making enterprises and organizations of Kherson were involved in determining the feasibility of implementing the developed forecasting models. Taking into account the level of their competence and the results of the conducted questionnaire, the need to conduct a study on the level of influence of the main financial indicators on the level of development of the region was determined.

Table 2

Example of calculation of the value of 1 point of qualification competencies expert / employee

\begin{tabular}{|c|c|c|c|c|c|c|c|c|c|c|}
\hline Employee & $\begin{array}{c}\text { Education, } \\
\text { points }\end{array}$ & $\mathrm{C}_{1}$ & $\begin{array}{l}\text { Work } \\
\text { expe- } \\
\text { rience, } \\
\text { months }\end{array}$ & $\mathrm{C}_{2}$ & $\begin{array}{l}\text { Producti- } \\
\text { vity of } \\
\text { labor, } \\
\text { UAH / h }\end{array}$ & $\mathrm{C}_{3}$ & $\frac{\bullet K}{3}$ & Qe, points & $\begin{array}{c}\text { Average } \\
\text { monthly } \\
\text { salary, } \\
\text { UAH. }\end{array}$ & $\begin{array}{c}\text { Cost of } \\
1 \text { point of } \\
\text { quality }\end{array}$ \\
\hline No. 1 & 5 & 0.5 & 37 & 0.89 & 110 & 0.863 & 0.751 & 1.332 & 6500 & 4881.33 \\
\hline No. 2 & 7 & 0.167 & 55 & 0.748 & 145 & 0.495 & 0.47 & 2.129 & 8000 & 3758.49 \\
\hline No. 3 & 3 & 0.833 & 42 & 0.850 & 124 & 0.716 & 0.8 & 1.25 & 7000 & 5598.87 \\
\hline No. 4 & 4 & 0.667 & 23 & 1 & 118 & 0.779 & 0.815 & 1.227 & 6400 & 5217.31 \\
\hline No. 5 & 6 & 0.333 & 78 & 0.564 & 167 & 0.263 & 0.388 & 2.579 & 8500 & 3296.36 \\
\hline No. 6 & 8 & 0 & 128 & 0.173 & 192 & 0 & 0.058 & 17.318 & 9500 & 548.56 \\
\hline No. 7 & 5 & 0.5 & 150 & 0 & 185 & 0.074 & 0.191 & 5.229 & 10000 & 1912.28 \\
\hline \multirow[t]{3}{*}{ No. 8} & 2 & 1 & 61 & 0.701 & 97 & 1 & 0.9 & 1.111 & 7500 & 6751.97 \\
\hline & $\operatorname{Max}=8$ & & $\operatorname{Max}=150$ & & $\operatorname{Max}=192$ & & & & & \\
\hline & $\operatorname{Min}=2$ & & $\operatorname{Min}=23$ & & $\operatorname{Min}=97$ & & & & & \\
\hline
\end{tabular}

Source: own elaboration 
An effective index is suggested to use the index of the physical volume of the gross regional product (in the prices of the previous year) (9.4 from 10 points)). Among the most influential financial indicators that reflect the financial capacity of the local community (region), it is proposed to consider: corporate income $\operatorname{tax}(\mathrm{X} 1)$, value added tax on goods manufactured in Ukraine (X2), personal income tax (X3), single tax for small businesses (X4).

Using the reporting data for 2010-2017 and the formula for calculating the correlation coefficients, the following relationship was established between the performance indicator $(\mathrm{Y})$ and the factors indicated:

- $\mathrm{ryx}_{1}=0.474-$ in accordance with the scale of the assessment of the relation-ship of variables, the relationship between $\mathrm{Y}$ and $\mathrm{X}_{1}$ is considered average;

- $\mathrm{ryx}_{2}=0.038$ - the connection between $\mathrm{Y}$ and $\mathrm{X}_{2}$ is almost absent;

$-\mathrm{ryx}_{3}=-0.089-$ the relationship between $\mathrm{Y}$ and $\mathrm{X}_{3}$ is almost absent;

$-\mathrm{ryx}_{4}=-0.056$ - the connection between $\mathrm{Y}$ and $\mathrm{X}_{4}$ is almost absent.

The existing contradictions in terms of results, especially in determining the relationship between the performance indicator $(\mathrm{Y})$ and the personal income tax $\left(\mathrm{X}_{3}\right)$ and the Single Tax for Small Business Entities $\left(\mathrm{X}_{4}\right)$ are primarily related to the changes introduced in part changes in the minimum wage and the ratio between the minimum wage and the living wage. As a result, for individual entrepreneurs who used the simplified taxation system and have been classified in the second group of single tax payers, the volume of the single tax increased twice without the corre-sponding increase in volumes of manufactured products, works performed, services rendered. A similar situation was observed with respect to the income of individuals' income tax as a result of the growth of twice the minimum wage, with the full development of the working month and unchanged labor productivity, there was a significant increase in the volume of transfers of personal income tax, which was not supported by the results of the entity's economic activity management. Also, the share of workers who could take advantage of the tax social benefit at the time of payment of the tax on personal income decreased.
Also, a high level of connection between the average monthly wage of the population of the Kherson region and the amount of personal income tax $(r=0.995)$ and the Single Tax for small business entities $(r=0.925)$ were revealed.

In modern conditions, the low level of average monthly wages in the Kherson region and Ukraine in general, the use of advanced technologies for taxation of in-comes is a necessary component of paying decent wages to the socially vulnerable population and increasing the levels of competitiveness of products (works, services) and enterprises in general. Taking into account the above, based on the foreign experience of taxation of individuals' incomes, it was proposed to ensure the implementation of the following measures for workers of industrial enterprises in the region: non-taxation of $30 \%$ of the average wage in the manufacturing sector (in January 2019 the industry average salary amounted to $10388 \mathrm{UAH}$ ), that is, $3116.4 \mathrm{UAH}$; establishment of communication in determining the maximum amount of income to which the use of tax social benefits may be applied, and the size of the tax social benefit, with the size of the minimum wage on January 1 of the reporting year. That is, the maximum amount of income in 2019 will be $5840 \mathrm{UAH}$, the amount of tax privilege will be calculated in the proportional equivalent to $4173 \mathrm{UAH}$; the introduction of an additional tax of $7 \%$ on incomes, which is 3 times higher than the average wage in the production sector, that is, more than 31164 UAH.

Proposed offers for taxation of the socially vulnerable workers of manufacturing enterprises in 2019 will be reflected in Table 3 .

At the testing of the provided recommendations to "Amalteya" Ltd., it was established that the total salary payable to employees in January could increase by 175.6 thousand UAH or $17.7 \%$.

The average share of deductions from accrued wages amounted to only $5.3 \%$, which, in the conditions of permanent increase of prices for essential products and payment of housing and communal services, is the most important component in ensuring the creation of proper living conditions for the socially vulnerable population. Moreover, the growth of the size of the "net" wage will not only reduce the size of the indebtedness of

Table 3

Proposals for taxation of the socially vulnerable population manufacturing enterprises in 2019

\begin{tabular}{|l|c|c|c|c|}
\hline \multicolumn{1}{|c|}{ Indicator } & \multicolumn{3}{c|}{ Accrued wages (X), UAH } \\
\cline { 2 - 5 } & $\mathrm{X} \leq 3116.4$ & $3116.4<\mathrm{X} \leq 5840$ & $5840<\mathrm{X} \leq 31164$ & $31164<\mathrm{X}$ \\
\hline Interest rate of PIT,\% & 0 & 18 & 18 & 25 \\
\hline $\begin{array}{l}\text { The size of the tax allowance for the payment of personal } \\
\text { income tax (for taxpayers specified in subparagraph 1 of } \\
\text { clause 4 of Article 169 of the Tax Code of Ukraine), UAH }\end{array}$ & 3116.4 & $3116.4+0.5^{*} 4173$ & 3116.4 & 3116.4 \\
\hline The size of the personal income tax, UAH & 0 & $\begin{array}{c}\left(\mathrm{X}-0.5^{*} 4173-\right. \\
3116.4)^{*} 0.18\end{array}$ & $(\mathrm{X}-3116.4)^{*} 0.18$ & $\begin{array}{c}(31164-3116.4)^{*} 0.18+ \\
+(\mathrm{X}-31164) * 0.25\end{array}$ \\
\hline
\end{tabular}

Source: own elaboration 
the socially vulnerable population for the use of housing and communal services, but also increase the purchasing power of the population and ensure the growth of the value added tax revenues to the State Budget of Ukraine (the correlation between the average monthly wage in the Kherson region and the value added tax on manufactured goods is 0.967 ).

\section{Conclusions and recommendations for further research}

The results of the study suggest that the introduction of a sound scientific and methodological approach to assessing and forecasting the level of development of the country and regions in particular will allow not only to identify problem areas in the development of the respective territories, but also to get the potential investor reliable information about the real state of affairs and to determine the justification of further investment in the activity of the research object. Using an unjustified scientific and methodological approach not only can distort the real state of affairs in the regions and the country in general, but also send in the conditions of the crisis limited financial resources of the State and local budgets to improve the indicators that have a minor impact on the development of the economy.

It is proved that in current crisis conditions, the functioning of the national economy, state authorities should implement a more effective discretionary fiscal policy aimed at reducing the tax burden in the formation of the wage fund of the socially vulnerable population.

\section{References:}

Bohdaniuk, I., Kolisnichenko, V., \& Ustymenko, O. (2018). Audit as a form of control of the state financial inspection of Ukraine. Baltic Journal of Economic Studies, vol. 4, no. 5, pp. 31-35. doi: 10.30525/2256-0742/2018-4-5-31-35

Guziejewska, B. (2015). Designing a revenue structure in local self-government entities in Poland: taxes versus grants. Equilibrium. Quarterly Journal of Economics and Economic Policy, vol. 10, no. 3, pp. 45-63.

Kichurchak, M. V. (2016). Trends and prospects for the development of fiscal decentralization in the practice of reproduction of public goods in Ukraine. Economic forum, vol. 3, pp. 272-280.

Lozova, O. V. (2012). Forecasting of social and economic development as an instrument of state regulation of social processes in Ukraine. Bulletin of Donetsk National University of Economics and Trade named after M. TuganBaranovsky. Series of Economic Sciences, vol. 4, no. 56, pp. 28-36.

Makarenko, S. M., Oliinyk, N. M., \& Kazakova, T. S. (2018). Improving the method approach to the rating evaluation of employees as professional career development. Baltic Journal of Economic Studies, vol. 4, no. 5 December, pp. 179-187. doi: 10.30525/2256-0742/2018-4-5-179-187

Monitorynh sotsialno-ekonomichnoho rozvytku rehioniv Ukrainy za sichen-zhovten 2018 roku [Monitoring of socio-economic development of regions of Ukraine for January-October 2018] (2018). Scientific Research Center for Industrial Problems of Development of the National Academy of Sciences of Ukraine. Available at: https://cutt.ly/ Aj10j2q

Pro vnesennia zmin u dodatky 1 i 2 do Poriadku provedennia otsinky rezultativ diialnosti Rady ministriv Avtonomnoi Respubliky Krym, oblasnykh, Kyivskoi ta Sevastopolskoi miskykh derzhavnykh administratsii: Postanova Kabinetu Ministriv Ukrainy vid 9 kvitnia 2012 r. № 335 [On Amendments to Annexes 1 and 2 to the Procedure for Evaluation of the Results of the Activity of the Council of Ministers of the Autonomous Republic of Crimea, Kyiv region and Sevastopol City State Administrations: Resolution of the Cabinet of Ministers of Ukraine dated April 9, 2012 No. 335]. Cabinet of Ministers of Ukraine. Available at: https://zakon.rada.gov.ua/laws/show/335-2012$\% \mathrm{D} 0 \% \mathrm{BF} \# \mathrm{n} 2$

Pro zaprovadzhennia provedennia otsinky rezultativ diialnosti Rady ministriv Avtonomnoi Respubliky Krym, oblasnykh, Kyivskoi ta Sevastopolskoi miskykh derzhavnykh administratsii: Postanova Kabinetu Ministriv Ukrainy vid 9 chervnia $2011 \mathrm{r}$. № 650 [On introduction of an evaluation of the results of the activity of the Council of Ministers of the Autonomous Republic of Crimea, Kyiv region and Sevastopol city state administrations: Resolution of the Cabinet of Ministers of Ukraine dated June 9, 2011 No. 650]. Cabinet of Ministers of Ukraine. Available at: https://zakon.rada.gov.ua/laws/show/650-2011-\%D0\%BF

Soloviova, N. I., Makarenko, S. M., \& Oliinik, N. M. (2016). Methodological correctness of forecast estimation of the regional socioeconomic development parameters. Actual problems of economics, vol. 11, no. 185, pp. $268-277$.

Derzhavna sluzhba statystyky Ukrainy [State Statistics Service of Ukraine] (2018). Available at: http://ukrstat.gov.ua (accessed 21.03.2019).

Tyukhtenko, N., Makarenko, S., Oliinyk, N., Gluc, K., Portugal, Ed., \& Rybachok, S. (2019). Innovative development of the regions: cooperation between enterprises and state institutions. Marketing and Management of Innovations, vol. 3, pp. 354-365. doi: http://doi.org/10.21272/mmi.2019.3-27

Yaroshenko, I. V., \& Semyhulina, I. B. (2015). Metodychni pidkhody shchodo stvorennia ta zabezpechennia funktsionyvannia systemy monitorynhu ta otsinky sotsialno-ekonomichnoho rozvytku rehioniv $\mathrm{v}$ Ukraini [Methodological approaches to the creation and maintenance of a system of monitoring and evaluation of socioeconomic development of regions in Ukraine]. Problems of the economy, vol. 1, pp. 180-186.

Zachosova, N. (2019). Innovative approach in the estimatology of financial institutions economic security: possibilities of use in management and regulatory activity within the means of provision of the state financial security. Baltic Journal of Economic Studies, vol. 5, no. 2, pp. 45-56. doi: 10.30525/2256-0742/2019-5-2-45-56 